\title{
Mechanism controlling ovulation rate in ewes in relation to seasonal anoestrus
}

\author{
R. Webb*, G. Baxter, D. McBride, M. Ritchie and A. J. Springbett \\ AFRC Institute of Animal Physiology and Genetics Research, Roslin, Midlothian EH25 9PS, UK
}

\begin{abstract}
Summary. Three experiments were carried out during seasonal anoestrus in Finnish Landrace and Scottish Blackface ewes, to establish whether the differences between the breeds in ovulation rate are functional during the non-breeding season and are therefore independent of the mechanism controlling ovulation.

In Expt 1 , follicles $\geqslant 2 \mathrm{~mm}$ in diameter were dissected from the ovaries of both breeds and incubated individually for $2 \mathrm{~h}$ to assess their ability to secrete oestradiol and testosterone. In both breeds, follicles producing $\geqslant 500 \mathrm{pg}$ oestrogen $/ \mathrm{ml} / \mathrm{h}$ (oestrogenactive) were readily identifiable from a population producing less (oestrogen-inactive). The number of oestrogen-active follicles in each breed was similar to the number of ovulations near the end of the breeding season. Oestrogen-active follicles also had more luteinizing hormone $(\mathrm{LH})$ receptors and larger diameters than oestrogen-inactive follicles. There were, however, no significant differences between the two follicle types in follicular fluid or in-vitro testosterone concentrations.
\end{abstract}

In Expt 2, seasonally anoestrous Scottish Blackface ewes were unilaterally ovariectomized; the second ovary was removed 7 days later. Follicles from both ovaries were processed as described for Expt 1; oestrogen-active follicles were categorized according to their ability to produce $>500 \mathrm{pg} / \mathrm{ml} / \mathrm{h}$. There were twice as many oestrogen-active follicles in the second ovary as in the first ovary; the number of oestrogen-active follicles in the second ovary was also similar to the total number of oestrogen-active follicles in both ovaries of the Scottish Blackface ewes in Expt 1. There were no significant differences between the first and second ovaries for any of the other parameters measured in oestrogen-active follicles. There were no significant changes in peripheral gonadotrophin concentrations measured $24 \mathrm{~h}$ after removal of the first ovary.

In Expt 3, seasonally anoestrous ewes of both breeds were challenged with an ovulatory dose of human chorionic gonadotrophin (hCG) (750 iu). There was a significant difference in the mean number of ovulations between the breeds and it was representative for the breed (Finnish Landrace $2 \cdot 6 \pm 0 \cdot 2$; Scottish Blackface $1 \cdot 6 \pm 0 \cdot 2$ mean ovulations per ewe). None of the saline-treated controls ovulated.

The results demonstrated that the mechanism controlling the number of mature, oestrogen-active follicles, and hence ovulation rate, is functional during seasonal anoestrus. This conclusion was confirmed by the observation that compensatory ovarian hypertrophy also occurs during seasonal anoestrus.

Keywords: sheep; follicle; ovulation rate; steroidogenesis; seasonal anoestrus

\section{Introduction}

As follicles grow and develop they acquire a number of characteristics including significant numbers of granulosa cell luteinizing hormone $(\mathrm{LH})$ receptors and the ability to secrete large

\footnotetext{
*Reprint requests.
} 
quantities of oestradiol (Carson et al., 1979; England et al., 1981a; Webb \& England, 1982a). The measurement of oestradiol production in vitro by individual follicles, during the follicular phase of the oestrous cycle, has demonstrated the presence of two distinct populations of follicles, oestrogen-active and oestrogen-inactive (Webb et al., 1989). The number of oestrogen-active follicles, those capable of producing $>500 \mathrm{pg} / \mathrm{ml} / \mathrm{h}$ in vitro, is equivalent to the ovulation rate for the breed. Mature follicles, possessing significant numbers of thecal and granulosa cell $\mathrm{LH}$ receptors are present during the luteal and follicular phases of the oestrous cycle, the number of these potential ovulatory follicles being similar to the mean number of ovulations per ewe for the breed (England et al., 1981b). Also, follicles can be induced to ovulate during the luteal phase by treatment with human chorionic gonadotrophin (hCG) (see Scaramuzzi \& Hoskinson, 1984; Driancourt et al., 1988), the number of induced corpora lutea being typical of the breed.

The aim of the present studies was to establish whether the mechanism controlling the number of potential ovulatory follicles, and hence ovulation rate, is functional during seasonal anoestrus as well as during the oestrous cycle in ewes. A series of three experiments was carried out during seasonal anoestrus. The first compared follicle populations (oestrogen-active and oestrogeninactive follicles) in Finnish Landrace and Scottish Blackface ewes, two breeds with significant differences in ovulation rate, the mean number of ovulations per ewe was $\sim 3.4$ in Finnish Landrace and $\sim 1.4$ in Scottish Blackface (Wheeler \& Land, 1977). The second determined whether compensatory ovarian hypertrophy, as measured by the number of oestrogen-active follicles, occurs after unilateral ovariectomy. The third challenged the ovaries of ewes of both breeds with an ovulatory dose of hCG, to assess the number of follicles capable of ovulating at the time of challenge.

\section{Materials and Methods}

\section{Animals}

The three experiments were carried out during seasonal anoestrus (June and July) in parous Finnish Landrace and Scottish Blackface ewes, 2-6 years old, at the farms of the AFRC Institute of Animal Physiology and Genetics Research in Scotland. Ewes were kept on grass with supplementary feed as dictated by normal husbandry.

\section{Experimental designs}

Experiment 1. The two experimental groups, Group I, Finnish Landrace ewes $(n=9)$ and Group 2, Scottish Blackface ewes $(n=7)$, were ovariectomized. All follicles $\geqslant 2 \mathrm{~mm}$ in diameter were then dissected and incubated individually for $2 \mathrm{~h}$ in M199 to measure production of oestradiol and testosterone in vitro as this has been shown to be a good measure of synthesis de novo (Webb \& England, 1982a). After incubation, all follicles were stored in liquid nitrogen. ${ }^{125}$ I-labelled hCG-binding analysis was carried out on the thecal and granulosa cells from follicles $\geqslant 3 \mathrm{~mm}$ in diameter, as described previously (Webb \& England, 1982a, b). During the hCG-binding measurements, numbers of granulosa cells were assessed in an aliquot of the separated granulosa cells by counting in a haemocytometer. Numbers of granulosa cells were also counted on all the other follicles ( $<3 \mathrm{~mm}$ diameter) stored in liquid nitrogen. At this stage, follicular fluid was collected, as described by Webb \& England (1982a), and stored at $-20^{\circ} \mathrm{C}$ for the measurement of concentrations of oestradiol and testosterone (England et al., 1981a; Webb et al., 1985b).

Experiment 2. Scottish Blackface ewes $(n=6)$ were unilaterally ovariectomized and the remaining ovary was removed 7 days later. The first ovary acted as the control and was compared with the second ovary. The ovaries were processed as in Expt 1. Blood was sampled via jugular venepuncture (five samples at intervals of $100 \mathrm{~min}$ ) on the day before and the day after removal of the first ovary. Plasma was stored at $-20^{\circ} \mathrm{C}$ for radioimmunoassay for $\mathrm{LH}$ and follicie-stimulating hormone (FSH).

Experiment 3. Ewes were divided into four groups: Group I, Finnish Landrace ewes $(n=20)$ received 750 iu hCG (Chorulon: Intervet, Cambridge, UK) dissolved in $2.5 \mathrm{ml}$ sterile water; Group 2, Scottish Blackface ewes $(n=20)$ received 750 iu hCG; Group 3, Finnish Landrace ewes $(n=10)$ received saline only; Group 4, Scottish Blackface ewes $(n=10)$ received saline only. This dose of hCG was selected to ensure a maximal ovulatory challenge since $250-500 \mathrm{iu}$ hCG is effective in sheep during the breeding season (see Hunter, 1980) and 750 iu has been shown to induce ovulation during seasonal anoestrus (Driancourt et al., 1990). All ewes were injected intravenously. Ovulation rate was assessed by laparoscopy $64.90 \mathrm{~h}$ after treatment to ensure that hCG had not induced the ovulation of successive groups of follicles (Radford et al., 1984) 


\section{Hormone and $\mathrm{LH}$ receptor assays}

Oestradiol and testosterone. Concentrations of both hormones in the culture media and follicular fluid were determined by radioimmunoassay as described by Webb et al. (1985b, 1989). The intra- and interassay coefficients of variation were 13.5 and $11.9 \%$, respectively, for oestradiol with the minimum detectable value at $0.5 \mathrm{pg} /$ tube; and 10.6 and $11.4 \%$, respectively, for testosterone, with the minimum detectable value at $1.7 \mathrm{pg}$ per tube.

$\boldsymbol{L H}$ and $\boldsymbol{F S H}$. Concentration of $\mathrm{LH}$ in peripheral plasma was determined by radioimmunoassay as described by Martensz et al. (1976) and Webb et al. (1985a). The intra- and interassay coefficients of variation were $4 \cdot 4$ and $11.0 \%$, respectively, with the minimum detectable value at $0.4 \pm 0.02 \mathrm{ng} / \mathrm{ml}$. Concentration of FSH in peripheral plasma was determined by radioimmunoassay as described by McNeilly et al. (1976) and Webb et al. (1985a). The intra- and interassay coefficients of variation were 8.8 and $9.8 \%$, respectively, with the minimum detectable value at $24 \cdot 2 \pm 5 \cdot 9 \mathrm{ng} / \mathrm{ml}$.

$L H$ receptor assay. Analysis for $\mathbf{L H}$ receptors was carried out on all follicles $\geqslant 3 \mathrm{~mm}$ diameter, as described by Webb \& England $(1982 \mathrm{a}, \mathrm{b})$. The specific binding of the radiolabel to thecal and granulosa cells is expressed as fmol ${ }^{125}$ I-labelled hCG bound/4g DNA. DNA was determined by the method of Burton (1956). The hCG (Serono, BISFR3) used for iodination had a potency of $12154 \mathrm{iu} / \mathrm{mg}$. The hCG (Organon, PR300), used for assessing nonspecific binding, had a potency of $3224 \mathrm{iu} / \mathrm{mg}$. The iodinated hCG had a specific activity of $23 \cdot 2 \mu \mathrm{Ci} / \mu \mathrm{g}$, with an active fraction of $40 \cdot 2 \%$.

\section{Statistical analyses}

Most of the measurements taken on the follicles had a skewed distribution and these were transformed to a logarithmic scale before analysis to give an approximately normal distribution. Differences between breeds and oestrogen-active or oestrogen-inactive follicles were investigated using analysis of variance and incorporating a multiple-comparison test (Scheffé, 1959). A log-linear model was fitted to the data on follicle size for the two breeds (Expt 1), to investigate possible differences in the size distribution between the breeds. Correlations were calculated on the log scale for measurements with a skewed distribution. A non-parametric test (Wilcoxon two-sample rank test) was used to compare the number of oestrogen-active follicles in the two breeds.

\section{Results}

\section{Experiment 1: comparison between breeds}

\section{Follicle populations based on in-vitro oestradiol production}

Using a bimodal distribution from a larger number of ewes during the breeding season (Webb et al., 1989), follicles secreting $\geqslant 500 \mathrm{pg} / \mathrm{ml} / \mathrm{h}$ were designated oestrogen-active and the remaining follicles designated oestrogen-inactive. The Finnish Landrace ewes had significantly more oestrogenactive follicles than Scottish Blackface ewes (Table 1), but there was no significant difference between the breeds in the number of antral follicles $\geqslant 2.0 \mathrm{~mm}$ diameter (Finnish Landrace, $13.4 \pm 2 \cdot 6$; Scottish Blackface, $12.9 \pm 1 \cdot 1$ ). As was found during the breeding season (Webb et al., 1989), the Finnish Landrace ewes had a higher proportion of follicles in the $4 \cdot 1-5.0 \mathrm{~mm}$ range $(P<0.01)$ than the Scottish Blackface ewes (Table 2), but a significantly lower proportion $(P<0.05)$ of follicles in the $5 \cdot 1-7.0 \mathrm{~mm}$ range.

\section{Functional characteristics}

Oestrogen-active follicles. Scottish Blackface ewes had significantly larger oestrogen-active follicles $(P<0.01)$ than the Finnish Landrace ewes (Table 3), but the mean total number of granulosa cells in oestrogen-active follicles per ewe indicated no significant difference between Finnish Landrace $\left(5.64 \pm 1.08 \times 10^{6} ; n=8\right)$ and Scottish Blackface $\left(4.47 \pm 0.64 \times 10^{6} ; n=6\right)$ ewes. There was no significant difference between the breeds in any of the other parameters (Table 3 ), including in-vitro oestradiol concentrations.

Oestrogen-inactive follicles. There was no significant difference between the breeds (Table 3), except that Finnish Landrace ewes had significantly higher concentrations of oestradiol in the follicular fluid than Scottish Blackface $(P<0.05)$ ewes. 
Table 1. Distribution of follicles in two breeds of sheep, during seasonal anoestrus, based on in-vitro production of oestradiol

\begin{tabular}{lcccc}
\hline & \multicolumn{4}{c}{ Oestradiol $(\mathrm{pg} / \mathrm{ml} / \mathrm{h})$} \\
\cline { 2 - 5 } & $<20$ & $20-100$ & $100-500$ & $>500$ \\
\hline Finnish Landrace $(n=9)$ & & & & \\
$\quad$ Total number of follicles & 16 & 10 & 13 & 31 \\
$\quad$ Mean number of follicles/ewe & $1 \cdot 8 \pm 0 \cdot 5$ & $1 \cdot 1 \pm 0 \cdot 4$ & $1 \cdot 4 \pm 0 \cdot 3$ & $3 \cdot 4 \pm 0 \cdot 6^{\mathrm{a}}$ \\
$\quad$ Mean follicle diameter $(\mathrm{mm})$ & $3 \cdot 2 \pm 0 \cdot 2$ & $3 \cdot 1 \pm 0 \cdot 2$ & $4 \cdot 0 \pm 0 \cdot 4$ & $3 \cdot 7 \pm 0 \cdot 2$ \\
Scottish Blackface $(n=7)$ & & & & \\
$\quad$ Total number of follicles & 14 & 22 & 10 & 14 \\
$\quad$ Mean number of follicles/ewe & $2 \cdot 0 \pm 0 \cdot 5$ & $3 \cdot 1 \pm 0 \cdot 4$ & $1 \cdot 4 \pm 0 \cdot 4$ & $2 \cdot 0 \pm 0 \cdot 4^{\mathrm{b}}$ \\
Mean follicle diameter $(\mathrm{mm})$ & $3 \cdot 2 \pm 0 \cdot 3$ & $3 \cdot 6 \pm 0.3$ & $3 \cdot 9 \pm 0 \cdot 4$ & $4 \cdot 7 \pm 0 \cdot 3$ \\
\hline
\end{tabular}

a vs. b significantly different $(P<0-05$; Wilcoxon's two-sample rank test).

Table 2. Distribution of follicles in two breeds of sheep based on follicle diameter

\begin{tabular}{|c|c|c|c|c|c|}
\hline & \multicolumn{5}{|c|}{ Follicle diameter $(\mathrm{mm})$} \\
\hline & $2 \cdot 1-3 \cdot 0$ & $3 \cdot 1-4 \cdot 0$ & $4 \cdot 1-5 \cdot 0$ & $5 \cdot 1 \cdot 6 \cdot 0$ & $6 \cdot 1-7 \cdot 0$ \\
\hline \multicolumn{6}{|l|}{ Finnish Landrace } \\
\hline $\begin{array}{l}\text { Total number of follicles in each } \\
\text { size category (from } 9 \text { ewes) }\end{array}$ & $\begin{array}{c}27 \\
(3 \cdot 0 \pm 0 \cdot 5)\end{array}$ & $\begin{array}{c}20 \\
(2 \cdot 2 \pm 0 \cdot 5)\end{array}$ & $\begin{array}{c}17 \\
(1.9 \pm 0.5)\end{array}$ & $\begin{array}{c}6 \\
(0 \cdot 7 \pm 0 \cdot 2)\end{array}$ & $\begin{array}{c}0 \\
(0.0 \pm 0.0)\end{array}$ \\
\hline \multicolumn{6}{|l|}{ Scottish Blackface } \\
\hline $\begin{array}{l}\text { Total number of follicles in each } \\
\text { size category (from } 7 \text { ewes) }\end{array}$ & $\begin{array}{c}20 \\
(2 \cdot 9 \pm 0 \cdot 6)\end{array}$ & $\begin{array}{c}19 \\
(2 \cdot 7 \pm 0 \cdot 6)\end{array}$ & $\begin{array}{c}8 \\
(1 \cdot 1 \pm 0 \cdot 4)\end{array}$ & $\begin{array}{c}9 \\
(1 \cdot 3 \pm 0 \cdot 3)\end{array}$ & $\begin{array}{c}4 \\
(0 \cdot 6 \pm 0 \cdot 3)\end{array}$ \\
\hline
\end{tabular}

Mean number of follicles/ewe \pm s.e.m. in each size category is shown in parentheses.

Oestrogen-active follicles were significantly larger $(P<0.05)$ than oestrogen-inactive follicles in the Scottish Blackface, but not in the Finnish Landrace, ewes. Oestrogen-active follicles, in both breeds, had more granulosa cells $(P<0.05)$, higher concentrations of oestradiol in the follicular fluid $(P<0.001)$ and more theca $(P<0.001)$ and granulosa $(P<0.001)$ cell LH receptors. There was no significant difference between the breeds in concentrations of testosterone in the follicular fluid $(P=0.06)$ or testosterone secretion in vitro $(P>0 \cdot 10)$.

Total follicle population. Taking all follicles, there was a significant correlation between oestradiol production in vitro and concentrations of oestradiol in follicular fluid in both Finnish Landrace ( $r=0.873, P<0.001)$ and Scottish Blackface $(r=0.794, P<0.001)$ ewes. In both breeds, follicles producing $\sim 500 \mathrm{pg}$ oestradiol $/ \mathrm{ml} / \mathrm{h}$ in vitro had $\sim 70 \mathrm{ng}$ follicular fluid oestradiol $/ \mathrm{ml}$.

\section{Experiment 2: effect of unilateral ovariectomy}

This experiment used Scottish Blackface ewes only. As in Expt 1, follicles were divided into oestrogen-active ( $\geqslant 500 \mathrm{pg} / \mathrm{ml} / \mathrm{h}$ in vitro) and oestrogen-inactive. Taking both ovaries, follicles producing $\sim 500 \mathrm{pg}$ oestradiol $/ \mathrm{ml} / \mathrm{h}$ in vitro had $\sim 75 \mathrm{ng}$ oestradiol $/ \mathrm{ml}$ follicular fluid. The mean $( \pm$ s.e.m.) number of oestrogen-active follicles in the second ovary $(2.33 \pm 0.42)$ was significantly $(P<0.05)$ greater than in the first ovary $(1 \cdot 17 \pm 0.40)$, removed 7 days earlier.

The differences between the first ovary and the second ovary were similar for oestrogen-active and oestrogen-inactive follicles and so the data from the two ovaries were pooled. All of the characteristics (Table 4) were significantly different $(P<0.05)$, except for concentrations of testosterone in follicular fluid. 
Table 3. Geometric mean ( \pm s.e.m.) characteristics of oestrogen-active and oestrogen-inactive follicles from seasonal anoestrous Finnish Landrace $(n=9)$ and Scottish Blackface $(n=7)$ ewes

\begin{tabular}{|c|c|c|c|c|}
\hline & \multicolumn{2}{|c|}{ Finnish Landrace } & \multicolumn{2}{|c|}{ Scottish Blackface } \\
\hline & $\begin{array}{l}\text { Oestrogen- } \\
\text { active follicles }\end{array}$ & $\begin{array}{l}\text { Oestrogen- } \\
\text { inactive follicles }\end{array}$ & $\begin{array}{l}\text { Oestrogen- } \\
\text { active follicles }\end{array}$ & $\begin{array}{l}\text { Oestrogen- } \\
\text { inactive follicles }\end{array}$ \\
\hline Follicle diameter* (mm) & $3 \cdot 7 \pm 0 \cdot 2^{a}$ & $\begin{array}{c}3 \cdot 4 \pm 0 \cdot 2 \\
(39)\end{array}$ & $\begin{array}{c}4 \cdot 7 \pm 0 \cdot 3^{b x} \\
(14)\end{array}$ & $\begin{array}{c}3 \cdot 6 \pm 0 \cdot 2^{y} \\
(46)\end{array}$ \\
\hline $\begin{array}{l}\text { Number of granulosa } \\
\text { cells* }\left(\times 10^{-6}\right)\end{array}$ & $\begin{array}{c}1 \cdot 45 \pm 0 \cdot 16^{v} \\
(31)\end{array}$ & $\frac{1 \cdot 02 \pm 0.09^{w}}{(38)}$ & ${ }_{(14)}^{1.91 \pm 0.24^{x}}$ & $\begin{array}{c}1 \cdot 29 \pm 0 \cdot 13^{y} \\
(46)\end{array}$ \\
\hline $\begin{array}{l}\text { In-vitro production of } \\
\text { oestradiol }(\mathrm{pg} / \mathrm{ml} / \mathrm{h})\end{array}$ & $1152 \pm 128 \cdot 4$ & $45 \cdot \underset{(39)}{ \pm} 10 \cdot 7$ & $1211 \pm 216 \cdot 2$ & $\begin{array}{c}39 \cdot 7 \pm 7 \cdot 2 \\
(46)\end{array}$ \\
\hline $\begin{array}{l}\text { Oestradiol in follicular } \\
\text { fluid }(\mathrm{ng} / \mathrm{ml})\end{array}$ & $135 \cdot 6 \pm 28 \cdot 6^{v}$ & $11 \cdot 4 \pm 2 \cdot 2^{2 w}$ & $111 \cdot 7 \pm 44 \cdot 0^{x}$ & $\begin{array}{c}6 \cdot 6 \pm 1 \cdot 0^{\text {by }} \\
(40)\end{array}$ \\
\hline $\begin{array}{l}\text { In-vitro production of } \\
\text { testosterone }(\mathrm{pg} / \mathrm{ml} / \mathrm{h})\end{array}$ & $\begin{array}{c}496 \cdot 0 \pm 94 \cdot 7 \\
(31)\end{array}$ & $\begin{array}{c}493 \cdot 7 \pm 77 \cdot 9 \\
(36)\end{array}$ & $\begin{array}{c}1199 \cdot 9 \pm 425 \cdot 4 \\
(\mathrm{I} 4)\end{array}$ & $563 \cdot 1 \pm 74 \cdot 4$ \\
\hline $\begin{array}{l}\text { Testosterone in follicular } \\
\text { fluid }(\mathrm{ng} / \mathrm{ml})\end{array}$ & $\begin{array}{c}33 \cdot 2 \pm 6 \cdot 8 \\
(30)\end{array}$ & $\begin{array}{c}55 \cdot 9 \pm 9 \cdot 4 \\
(33)\end{array}$ & $\begin{array}{c}41 \cdot 0 \pm 19 \cdot 8 \\
(\text { II })\end{array}$ & $51 \cdot 2 \pm 11 \cdot 6$ \\
\hline $\begin{array}{l}\text { Concentration of granulosa } \\
\text { cell LH receptors } \\
\text { (fmol } / \mu \mathrm{g} \mathrm{DNA} \text { ) }\end{array}$ & $\frac{0 \cdot 62 \pm 0 \cdot 09^{v}}{(22)}$ & $0 \cdot 21 \pm 0 \cdot 14^{\mathrm{w}}$ & $\begin{array}{c}0 \cdot 56 \pm 0 \cdot 17^{x} \\
(13)\end{array}$ & $\begin{array}{c}0.25 \pm 0.04^{y} \\
(29)\end{array}$ \\
\hline $\begin{array}{l}\text { Concentration of theca } \\
\text { cell LH receptors } \\
\text { (fmol/ } / \text { g DNA) }\end{array}$ & $\begin{array}{c}0.37 \pm 0.07^{v} \\
(22)\end{array}$ & $\begin{array}{c}0.19 \pm 0.03^{w} \\
(25)\end{array}$ & $\begin{array}{c}0.30 \pm 0.05^{x} \\
(13)\end{array}$ & $\begin{array}{l}0 \cdot 16 \pm 0.00^{y} \\
(29)\end{array}$ \\
\hline
\end{tabular}

Number of follicles in parentheses; LH, luteinizing hormone.

*Arithmetic means.

Across rows, a vs. $\mathrm{b}, \mathrm{v}$ vs. $\mathrm{w}$ and $\mathrm{x}$ vs. $\mathrm{y}$ significantly different $(P<0.05)$.

Table 4. Effect of unilateral ovariectomy on geometric mean ( \pm s.e.m.) characteristics of oestrogenactive and oestrogen-inactive follicles from seasonal anoestrous Scottish Blackface ewes $(n=6)$

\begin{tabular}{|c|c|c|c|c|}
\hline & \multicolumn{2}{|c|}{ First ovary* } & \multicolumn{2}{|c|}{ Second ovary* } \\
\hline & $\begin{array}{l}\text { Oestrogen- } \\
\text { active follicles }\end{array}$ & $\begin{array}{l}\text { Oestrogen- } \\
\text { inactive follicles }\end{array}$ & $\begin{array}{l}\text { Oestrogen- } \\
\text { active follicles }\end{array}$ & $\begin{array}{c}\text { Oestrogen- } \\
\text { inactive follicles }\end{array}$ \\
\hline Follicle diameter $\dagger(\mathrm{mm})$ & $4 \cdot 4 \pm 0 \cdot 4$ & $\begin{array}{c}3 \cdot 3 \pm 0 \cdot 2 \\
(25)\end{array}$ & $\begin{array}{c}4.9 \pm 0.3 \\
(14)\end{array}$ & $\begin{array}{c}3 \cdot 4 \pm 0 \cdot 2 \\
(30)\end{array}$ \\
\hline $\begin{array}{l}\text { Number of granulosa } \\
\text { cells } \dagger\left(\times 10^{-6}\right)\end{array}$ & $2 \cdot 23 \pm 0.19$ & $1 \cdot 27 \underset{(24)}{ \pm 0} 0 \cdot 17$ & $2 \cdot 29 \pm 0 \cdot 28$ & $1 \cdot 16 \pm 0.09$ \\
\hline $\begin{array}{l}\text { In-vitro production of } \\
\text { oestradiol }(\mathrm{pg} / \mathrm{ml} / \mathrm{h})\end{array}$ & $1097 \cdot 3 \pm \frac{ \pm}{(7)} 394 \cdot 0$ & $\begin{array}{c}39 \cdot 2 \pm 9 \cdot 9 \\
(25)\end{array}$ & $\begin{array}{c}1944 \cdot 1 \pm 489 \cdot 5 \\
(14)\end{array}$ & $36 \cdot 0 \pm 5 \cdot 5$ \\
\hline $\begin{array}{l}\text { Oestradiol in follicular } \\
\text { fluid }(\mathrm{ng} / \mathrm{ml})\end{array}$ & $97.60 \pm \frac{40.82}{(7)}$ & $9 \cdot 08 \pm 2.51$ & $120 \cdot 59 \pm 66 \cdot 44$ & $8 \cdot 64 \underset{(27)}{ \pm} 2 \cdot 00$ \\
\hline $\begin{array}{l}\text { In-vitro production of } \\
\text { testosterone }(\mathrm{pg} / \mathrm{m} / / \mathrm{h})\end{array}$ & $1769 \cdot 0 \underset{(6)}{ \pm} 662 \cdot 5$ & $522 \cdot 4 \underset{(24)}{ \pm} 113 \cdot 4^{\mathrm{a}}$ & $\begin{array}{c}3715 \cdot 0 \pm 963 \cdot 7 \\
(14)\end{array}$ & $\frac{1439 \cdot 0 \pm 232 \cdot 2^{b}}{(30)}$ \\
\hline $\begin{array}{l}\text { Testosterone in follicular } \\
\text { fluid }(\mathrm{ng} / \mathrm{ml})\end{array}$ & $113 \cdot 3 \underset{(7)}{ \pm} 69 \cdot 51$ & $\frac{49 \cdot 4 \pm 17 \cdot 23}{(21)}$ & $131 \cdot 7 \pm 58 \cdot 96$ & $113 \cdot 4 \pm 21.21$ \\
\hline $\begin{array}{l}\text { Concentration of granulosa } \\
\text { cell LH receptors } \\
\text { (fmol } / \mu \mathrm{g} \text { DNA) }\end{array}$ & $0.49 \pm \frac{0}{(6)} 0.18$ & $0.26 \pm 0.09$ & $\begin{array}{c}0.27 \pm 0.09 \\
(13)\end{array}$ & $\begin{array}{c}0.19 \pm 0.03 \\
(19)\end{array}$ \\
\hline $\begin{array}{l}\text { Concentration of theca } \\
\text { cell LH receptors } \\
\text { (fmol/ } / \mu \text { DNA) }\end{array}$ & $0 \cdot 44 \pm \frac{ \pm}{(6)} 0 \cdot 17$ & $0 \cdot 33 \pm 0 \cdot 09^{a}$ & $0.26 \pm 0.03$ & $\begin{array}{c}0.15 \pm 0.02^{b} \\
(19)\end{array}$ \\
\hline
\end{tabular}

Number of follicles in parentheses; $\mathbf{L H}$, luteinizing hormone.

*First ovary was removed 7 days before the second ovary.

†Arithmetic means.

Across rows, a vs. b significantly different $(P<0 \cdot 01)$. 
Oestrogen-active follicles. There was no significant difference between the first and second ovaries for any of the parameters that were measured (Table 4).

Oestrogen-active follicles. Testosterone secretion in vitro was higher $(P<0.001)$ in the second ovary than in the first, and there were more theca $\mathrm{LH}$ receptors $(P<0.01)$ in the first ovary.

\section{Peripheral gonadotrophin concentration}

There was no significant difference in either geometric mean peripheral concentrations of $\mathrm{LH}$ or FSH between the day before unilateral ovariectomy and the day after ovariectomy. There was $0.87 \pm 0.15 \mathrm{ng} \mathrm{LH} / \mathrm{ml}$ on the day before ovariectomy compared with $0.96 \pm 0.04 \mathrm{ng} \mathrm{LH} / \mathrm{ml}$ on the day after ovariectomy; and $95.1 \pm 21.5 \mathrm{ng} \mathrm{FSH} / \mathrm{ml}$ on the day before ovariectomy compared with $105 \cdot 2 \pm 12 \cdot 2 \mathrm{ng} \mathrm{FSH} / \mathrm{ml}$ on the day after ovariectomy. As the standard errors show, there was large between-animal variation in $\mathrm{FSH}$, with mean values per ewe in the range $55 \cdot 4-142 \cdot 6 \mathrm{ng} / \mathrm{ml}$. Therefore, the mean FSH concentration for each ewe on the day after ovariectomy was expressed as a percentage of the value before ovariectomy $(100 \%)$. There was no significant increase after ovariectomy, with a mean of $103 \cdot 7 \pm 3 \cdot 3 \%$.

\section{Experiment 3: ovulation rate in seasonally anoestrous ewes}

None of the saline-treated ewes of either breed ovulated. In the treated Finnish Landrace ewes, $90 \%$ ( 18 of 20 ) ovulated after the hCG challenge, with a range $1-5$, compared with $75 \%$ ( 15 of 20 ) for the Scottish Blackface ewes, with a range 1-3 (Table 5). Taking all ewes there was a significant difference in the induced ovulation rate between the two breeds (Table 5). Taking only the ewes that ovulated, it was $2.6 \pm 0.2$ in the Finnish Landrace compared with $1.6 \pm 0.2$ in the Scottish Blackface ewes $(P<0.05$; Wilcoxon's two-sample rank test).

Table 5. Mean ovulation rate, and its distribution in two breeds of sheep after hCG challenge during seasonal anoestrus

\begin{tabular}{lcccccccc}
\hline & $\begin{array}{c}\text { Number of } \\
\text { ewes } \\
\text { per group }\end{array}$ & $\begin{array}{c}\text { Mean }( \pm \text { s.e.m.) } \\
\text { number of ovulations } \\
\text { per ewe* }\end{array}$ & \multicolumn{4}{c}{ Number of ovulations/ewe } \\
\hline Finnish Landrace & 20 & $2 \cdot 3 \pm 0 \cdot 3^{\mathrm{a}}$ & 2 & 2 & 7 & 7 & 1 & 1 \\
Scottish Blackface & 20 & $1 \cdot 2 \pm 0 \cdot 2^{\mathrm{b}}$ & 5 & 8 & 5 & 2 & 0 & 0 \\
\hline
\end{tabular}

*Includes ewes not ovulating; none of the saline-treated controls ( 10 of each breed) ovulated. a vs. b significantly different $(P<0.05$; Wilcoxon's two-sample rank test).

\section{Discussion}

The results demonstrated that genetic differences in the mechanism controlling ovulation rate are still functional during seasonal anoestrus. First, using the same criteria, the ability of follicles to produce $\geqslant 500 \mathrm{pg}$ oestradiol $/ \mathrm{ml} / \mathrm{h}$ in vitro, as in the breeding season (Webb et al., 1989), the mean number of oestrogen-active follicles/ewe (Finnish Landrace 3.4; Scottish Blackface 2.0) was as expected from the ovulation rate for the breed. Secondly, the number of follicles ovulating in response to an ovulatory dose of hCG was typical of the ovulation rate for the breed. Thirdly, compensatory ovarian hypertrophy also occurs during seasonal anoestrus; the number of oestrogen-active follicles had doubled by 7 days after unilateral ovariectomy.

Most of the oestrogen-active follicles appear capable of ovulating after a challenge with $750 \mathrm{iu}$ hCG. A preliminary report of these results (Webb, 1988) has been confirmed by Driancourt et al. 
(1990) in other breeds of sheep. The ovulation rate in the Finnish Landrace $(2 \cdot 6 \pm 0 \cdot 2)$ and the Scottish Blackface $(1.6 \pm 0.2)$ ewes was similar to that reported by Wheeler \& Land (1977), who also found an effect of season, with an ovulation rate of 2.6 in Finnish Landrace in March and 3.5 in November. In the present study, the rate of hCG-induced ovulation in the Finnish Landrace ewes was $2 \cdot 6 \pm 0 \cdot 2$, whereas the number of oestrogen-active follicles in Expt 1 was $3 \cdot 4 \pm 0 \cdot 6$. As well as a genetic effect of breed on ovulation rate, there appears to be an effect of season. It is not known why all of the oestrogen-active follicles are not capable of ovulating in response to hCG. As in the breeding season (England et al., 198 l b; Webb \& England, 1982a, b), oestrogen-active follicles had significantly more $\mathrm{LH}$ receptors than the oestrogen-inactive follicles, although the number was lower than during the late-follicular phase of the oestrous cycle (Webb \& England, 1982b). During seasonal anoestrus, progesterone affects follicle maturation, stimulating an increase in the number of follicular LH receptors and oestradiol secretion (Hunter et al., 1986), and enhancing hCG binding (Hunter \& Southee, 1987). The rise in ovulation rate in the middle of the breeding season may therefore be due to luteal progesterone-associated effects on the maturation of ovulatory follicles during the follicular phase, although other effects are involved, as this explanation does not account for the reduction in ovulation rate at the end of the breeding season (Wheeler \& Land, 1977).

The mechanism controlling the number of oestrogen-active follicles is responsive to unilateral ovariectomy, as demonstrated by a doubling in the number of oestrogen-active follicles in the remaining ovary. The number of oestrogen-active follicles in the second ovary after unilateral ovariectomy was also similar to the total number of oestrogen-active follicles in both ovaries of Scottish Blackface ewes in Expt $1(2 \cdot 3 \pm 0 \cdot 4$ vs. $2 \cdot 0 \pm 0 \cdot 4)$. The results from this study clarify previous equivocal work on whether compensatory ovarian hypertrophy can occur during seasonal anoestrus (Mallampati \& Casida, 1970; Dufour et al., 1971; Findlay \& Cumming, 1977). However, the previous results were based on observations such as weights of ovarian and follicular fluid and number of follicles. These gross changes do not appear to be sensitive enough to identify an effect consistently; in both this and previous studies, in the same breeds of sheep, ovulation rate was not related to the size of the antral follicle population (Webb et al., 1989). In the current study, there were significantly more $(P<0.05)$ follicles $\geqslant 2 \mathrm{~mm}$ diameter per ovary in the second ovary that was removed ( $10.8 \pm 0.4$ follicles) than in the first ovary $(7.0 \pm 1.0$ follicles), although none of the other characteristics (see Table 4) was significantly different.

Gonadotrophins are required for the growth of follicles $\geqslant 2 \mathrm{~mm}$ in diameter (Dufour et al., 1979; Webb \& Gauld, 1985a, b; McNeilly et al., 1986; Driancourt et al., 1988), but increases in gonadotrophin concentrations may not be required for compensatory hypertrophy. Findlay \& Cumming (1977) found no increase during seasonal anoestrus in peripheral FSH after unilateral ovariectomy. In the present study, no change in FSH concentration was found, although animals were only sampled intensively $24 \mathrm{~h}$ after unilateral ovariectomy. During the breeding season, an increase in FSH $5 \frac{1}{2}-12 \mathrm{~h}$ after unilateral ovariectomy was noted by Findlay \& Cumming (1977), although whether this is the reason for the compensatory ovarian hypertrophy is questioned by the results of Fry et al. (1987), in sheep during the breeding season, which suggested that compensation of ovulation rate in the remaining ovary after unilateral ovariectomy may be independent of release of gonadotrophins from the pituitary gland. No significant differences have been found in peripheral FSH or LH concentrations between entire Scottish Blackface and Finnish Landrace ewes during seasonal anoestrus (Webb et al., 1985a) despite the differences in the rate of hCG-induced ovulation demonstrated in Expt 3.

A number of follicular characteristics were similar to those in the breeding season (Webb et al., 1989). First, the number of oestrogen-active follicles was not related to the large antral follicle population, the number of follicles $\geqslant 2 \mathrm{~mm}$ diameter being similar in both breeds (Finnish Landrace 13.4 $\pm 2 \cdot 6$; Scottish Blackface 12.9 $\pm 1 \cdot 1$ ). Secondly, Scottish Blackface ewes had a higher proportion of follicles in the $5.1-7.0 \mathrm{~mm}$ range (Table 2), the Finnish Landrace ewes having no follicles $>6.0 \mathrm{~mm}$ in diameter. Thirdly, the mean follicular diameter of oestrogen-active follicles 
was significantly smaller in the Finnish Landrace ewes than in the Scottish Blackface ewes, suggesting that presumptive ovulatory follicles in the breeds with higher ovulation rates are selected at a smaller diameter, as occurs in the breeding season (Webb et al., 1989). Fourthly, there was no between-breed difference for in-vitro oestradiol production, indicating that granulosa cells from oestrogen-active follicles of the Finnish Landrace ewes produce more oestradiol/cell, despite having lower production of testosterone in vitro than the breed with the lower ovulation rate. Finally, oestrogen-active follicles produced similar amounts of testosterone in vitro and had concentrations of testosterone in follicular fluid similar to oestrogen-inactive follicles in both breeds, indicating that small antral follicles go through an androgen-dominated phase as shown previously for the breeding season (Moor et al., 1978; Carson et al., 1981; England et al., $1981 \mathrm{a}, \mathrm{b})$.

In-vitro production of oestradiol per oestrogen-active follicle, from ewes undergoing bilateral ovariectomy (Expt 1), was not different from that in oestrogen-active follicles from the first ovary removed after unilateral ovariectomy (Expt 2). In both experiments, there was a significant correlation between in-vitro production of oestradiol and concentrations of oestradiol in follicular fluid, indicating that the latter offers an alternative to measurement of oestradiol in vitro for assessing the number of oestrogen-active follicles. In Expt 2, there was approximately twice as much oestradiol and testosterone production in vitro (Table 4) by oestrogen-active follicles from the second ovary than in those dissected from the first ovary, although these differences did not attain statistical significance because of the large between-follicle variation. However, when expressed on a per ovary basis, there was a significant $(P<0.05)$ three- and four-fold difference in oestradiol and testosterone, respectively. The reason for this increase in steroid production is not known, as there appears to be no change in circulating gonadotrophin concentrations during the first $36 \mathrm{~h}$ after unilateral ovariectomy (Findlay \& Cumming, 1977; Expt 2), although gonadotrophin concentrations at later periods have not been measured.

The results from these studies have shown that the mechanism controlling the number of oestrogen-active follicles, and hence ovulation rate, in these two breeds is still functional during seasonal anoestrus. This conclusion is confirmed by the observation that compensatory ovarian hypertrophy, as measured by the number of oestrogen-active follicles and steroid output in vitro, does occur during seasonal anoestrus.

We thank B. Ritchie, B. Wilson and the staff of Blythbank and Dryden for technical assistance; M. R. Geary of Intervet Laboratories for supplying the hCG; NIDDK and the National Hormone and Pituitary Program (University of Maryland School of Medicine) and Professor M. Jutisz for gonadotrophin preparations; S. Lynch for antisera, I. K. Gauld for helpful discussions and J. Cherrie for typing the manuscript.

\section{References}

Burton, R. (1956) A study of the conditions and mechanism of diphenylamine reaction for the colorimetric estimation of deoxyribonucleic acid. Biochem. J. 62, 315-323.

Carson, R.S., Findlay, J.K., Burger, H.G. \& Trounson, A.O. (1979) Gonadotropin receptors of the ovine ovarian follicle during follicular growth and atresia. Biol. Reprod. 21, 75-87.

Carson, R.S., Findlay, J.K., Clarke, I.J. \& Burger, H. (1981) Estradiol, testosterone and androstenedione in ovine follicular fluid during growth and atresia. Biol. Reprod. 24, 105- 113.

Driancourt, M.A., Philipon, P., Locatelli, A., Jacques, E. \& Webb, R. (1988) Are differences in FSH concentrations involved in the control of ovulation rate in
Romanov and Ile-de-France ewes? J. Reprod. Fert. 83, 509-516.

Driancourt, M. A., Bodin, L., Boomarov, O., Thimonier, J. \& Elsen, J. M. (1990) Number of mature follicles ovulating after a challenge of human chorionic gonadotropin in different breeds of sheep of different physiological stages. J. Anim. Sci. 68, 719-724.

Dufour, J. J., Ginther, O.J. \& Casida, L.E. (1971) Compensatory hypertrophy after unilateral ovariectomy and destruction of follicles in the anestrous ewe. Proc. Soc. exp. Biol. Med. 138, 10681072.

Dufour, J.J., Cahill, L.P. \& Mauléon, P. (1979) Short and long term effects of hypophysectomy and unilateral ovariectomy of ovarian follicular populations in sheep. $J$. Reprod. Fert. 57, 302-309. 
England, B.G., Dahmer, M.K. \& Webb, R. (1981a) Relationship between follicular size and antral fluid steroid concentrations at three stages of the estrous cycle in the ewe. Biol. Reprod. 24, 1068-1075.

England, B.G., Webb, R. \& Dahmer, M.K. (1981b) Follicular steroidogenesis and gonadotropin binding to ovine follicles during the estrous cycle. Endocrinology $109,881-887$.

Findlay, J.K. \& Cumming, I.A. (1977) The effect of unilateral ovariectomy on plasma gonadotropin levels, estrus and ovulation rate in sheep. Biol. Reprod. 17, 178-183.

Fry, R.C., Clark, I.J. \& Cahill, L.P. (1987) Changes in gonadotrophin concentrations are not necessarily involved in ovarian compensation after unilateral ovariectomy in sheep. J. Reprod. Fert. 79, 45-48.

Hunter, R.H.F. (1980) Physiology and Technology of Reproduction in Female Domestic Animals. Academic Press, London.

Hunter, M.G. \& Southee, J.A. (1987) Treatment with progesterone affects follicular steroidogenesis in anoestrous ewes. Anim. Reprod. Sci. 14, 273-279.

Hunter, M.G., Southee, J.A., McLeod, B.J. \& Haresign, W. (1986) Progesterone pretreatment has a direct effect on GnRH-induced preovulatory follicles to determine their ability to develop into normal corpora lutea in anoestrous ewes. J. Reprod. Fert. 76, $349-363$.

Mallampati, R.S. \& Casida, L.E. (1970) Absence of ovarian compensatory hypertrophy after unilateral ovariectomy during the anoestrous season in the ewe. Proc. Soc. exp. Biol. Med. 134, 237240.

Martensz, N.D., Baird, D.T., Scaramuzzi, R.J. \& Van Look, P.F.A. (1976) Androstenedione and the control of luteinizing hormone in the ewe during seasonal anoestrus. J. Endocr. 69, 227-237.

McNeilly, J.R., McNeilly, A.S., Walton, J.S. \& Cunningham, F.J. (1976) Development and application of a heterologous radioimmunoassay for ovine follicle stimulating hormone. $J$. Endocr. 70, 69-79.

McNeilly, A.S., Jonassan, J.A. \& Fraser, H.M. (1986) Suppression of follicular development after chronic LHRH immunoneutralization in the ewe. $J$. Reprod. Fert. 76, 481-490.

Moor, R.M., Hay, M.F., Dott, H.M. \& Cran, D.G. (1978) Microscopic identification and steroidogenic function of atretic follicles in sheep. J. Endocr. 77, 309-318.

Radford, H.M., Avenell, J.A. \& Szell, A. (1984) Human chorionic gonadotrophin induces multiple ovulations in sheep. In Reproduction in Sheep, pp. 342-344. Eds D. R. Lindsay \& D. T. Pearce. Cambridge University Press, New York.
Scaramuzzi, R.J. \& Hoskinson, R.M. (1984) Active immunization against steroid hormones for increasing fecundity. In Immunological Aspects of Reproduction of Mammals, pp. 445-474. Ed. D. B. Crighton. Butterworths, London.

Scheffé, H. (1959) The Analysis of Variance. Wiley, New York.

Wheeler, A.G. \& Land, R.B. (1977) Seasonal variation in oestrus and ovarian activity of Finnish Landrace, Tasmanian Merino and Scottish Blackface ewes. Anim. Prod. 24, 363-376.

Webb, R. (1988) Control of ovulation rate is not seasonal in the ewe. J. Reprod. Fert. Abst ser. No. 2, abst. 23.

Webb, R. \& England, B.G. (1982a) Relationship between LH receptor concentrations in thecal and granulosa cells and in-vivo and in-vitro steroid secretion by ovine follicles during the preovulatory period. $J$. Reprod. Fert. 66, 169-180.

Webb, R. \& England, B.G. (1982b) Identification of the ovulatory follicle in the ewe: associated changes in follicular size, thecal and granulosa cell $\mathrm{LH}$ receptors, antral fluid steroids and circulatory hormones during the preovulatory period. Endocrinology 110, 873-881.

Webb, R. \& Gauld, I.K. (1985a) Genetics and physiology of follicle recruitment and maturation during seasonal anoestrus. In Endocrine Causes of Seasonal and Lactational Anoestrus in Farm Animals, pp. 19-28. Eds F. Ellendorf \& F. Elsaesser. Martinus Nijhoff, Dordrecht.

Webb, R. \& Gauld, I.K. (1985b) Folliculogenesis in sheep: control of ovulation rate. In Genetics of Reproduction in Sheep, pp. 261 274. Eds R. B. Land \& D. W. Robinson. Butterworths, London.

Webb, R., Baxter, G., Preece, R.D., Land, R.B. \& Springbett, A.J. (1985a) Control of gonadotrophin release in Scottish Blackface and Finnish Landrace ewes during seasonal anoestrus. J. Reprod. Fert. 73, 369-378.

Webb, R., Baxter, G., McBride, D., Nordblom, G.D. \& Shaw, M.P.K. (1985b) The measurement of testosterone and oestradiol-17\% using iodinated tracers and incorporating an affinity chromatography extraction procedure. J. Steroid Biochem. 23, 10431051.

Webb, R., Gauld, I.K. \& Driancourt, M.A. (1989) Morphological and functional characterization of large antral follicles in three breeds of sheep with different ovulation rates. J. Reprod. Fert. 87, 243-255.

Received 26 November 1990 